\title{
Studies on phytochemical, antioxidant, anti-inflammatory and analgesic activities of Euphorbia dracunculoides
}

Muhammad Majid ${ }^{1 *}$, Muhammad Rashid Khan ${ }^{1 *}$, Naseer Ali Shah², Ihsan UI Haq ${ }^{3}$, Muhammad Asad Farooq ${ }^{1}$, Shafi Ullah' , Anam Sharif ${ }^{1}$, Zartash Zahra' ${ }^{1}$, Tahira Younis ${ }^{1}$ and Moniba Sajid ${ }^{1}$

\begin{abstract}
Background: Plants provide an alternative source to manage various human disorders due to diverse metabolites. Euphorbia dracunculoides of family Euphorbiaceae is used by local practitioners in rheumatism, epilepsy, edema, snake bite, warts and also possesses diuretic and purgative effects. The present study evaluated the antioxidant, anti-inflammatory and analgesic activities of various extracts of E. dracunculoides. Further, phytochemical constituents of the leading extracts were also investigated.

Methods: Dry powder of E. dracunculoides was extracted with n-hexane (EDH), acetone (EDA), ethanol (EDE), ethanol + water (1:1) (EDEW) and methanol (EDM) and screened for phytochemical classes, total phenolic (TPC) and flavonoid content (TFC). Antioxidant effects of the extracts were manifested by in vitro multidimensional assays. The antiinflammatory and analgesic activities of the extracts were evaluated through carrageenan induced paw edema and hot plate test in rat. In addition, GC-MS analysis of EDH and HPLC-DAD analysis of EDEW was carried out to determine the presence of active constituents.

Results: Qualitative analysis of various extracts of $E$. dracunculoides assured the existence of tannins and coumarins while presence of anthraquinones and anthocyanins was not traced in these extracts. Maximum quantity of TPC and TFC was recorded in EDEW followed by EDE. EDEW and EDE showed significant antioxidant activities with therapeutic potential against hydroxyl and phosphomolybdate radicals, $\beta$-carotene bleaching assay and in reducing of iron while moderate to low scavenging abilities were recorded for DPPH, nitric oxide and for iron chelation. During antiinflammatory activity after $4 \mathrm{~h}$ of drug administration the $300 \mathrm{mg} / \mathrm{kg}$ body weight dose of EDH (68.660 $\pm 10.502 \%)$ and EDE (51.384 $\pm 8.623 \%)$ exhibited strong anti-inflammatory activity and reduced the carrageenan-induced paw edema in rat as compared to standard drug diclofenac sodium (78.823 $\pm 6.395 \%$ ). Treatment of rats with EDH (70.206 $\pm 5.445 \%)$ and EDE (56.508 $\pm 6.363 \%)$ after 90 min showed significant increase in percent latency time in hot plate test as compared to morphine (63.632 $\pm 5.449 \%)$ treatment in rat. GC-MS analysis of EDH indicated the presence of 30 compounds predominantly of steroids and terpenoids. HPLC-DAD analysis against known standards established the presence of rutin, catechin, caffeic acid and myricetin in EDEW.
\end{abstract}

Conclusion: Our results suggest that presence of various polyphenolics, terpenoids and steroids render E. dracunculoides with therapeutic potential for oxidative stress and inflammation related disorders.

Keywords: Euphorbia dracunculoides, Antioxidant, Anti-inflammatory, Analgesic, Terpenoids, Steroids

\footnotetext{
* Correspondence: majidpharma808@gmail.com; mrkhanqau@yahoo.com

'Department of Biochemistry, Faculty of Biological Sciences, Quaid-i-Azam

University, Islamabad, Pakistan

Full list of author information is available at the end of the article
} 


\section{Background}

Medicinal plants play an appealing role in modulation of several human disorders. Many civilizations and cultures like Chinese, Ayurvedic, Unani and Hindi has a confirm belief on these cures to treat their health related issues. Plants derived chemicals are important source of clinical agents that have sedative, anti-depressant, antioxidant, antispasmodic, anxiolytic, anti-inflammatory, immunomodulatory, analgesic, anti-pyretic, and cardio protective activities [1]. This customary herbal medicinal system is deep rooted in their cultures and habitats and knowledge of home remedies is conveyed accordingly to their descendants as the time goes [2].

During the normal metabolic process human body produce reactive oxygen species (ROS) and reactive nitrogen species (RNS) as byproduct to accomplish the normal physiological processes. Oxidative stress can be declared as a root cause for many diseases especially chronic inflammatory disorders such as rheumatism, diabetes, carcinomas, mutagenesis, sarcomas, aging and circulatory disorders [3]. Living cells possess an excellent defense mechanism to cope with damaging effects of free radicals and this is made possible by a variety of detoxifying enzymes and metabolites inside the body that scavenge free radicals in a professional way. Among them superoxide dismutase (SOD), catalase (CAT) and peroxidase (POD) are the main stream enzymes supported with scavengers and chelating agents. The indirectly acting antioxidants are very important in protecting body from deleterious effects of ROS/RNS. This group comprised thousands of compounds involved in free radical scavenging and most of them are derived from dietary sources such as vegetables and fruits.

We are much more endangered by free radicals than being secured by natural scavenging entities producing in our body in stressed conditions. Phytochemicals play a unique role in avoiding hazardous effects of free radicals [4]. Polyphenols are excellent free radical scavengers and inhibitors of lipid peroxidation. Terpenoids and steroids are useful metabolites for various metabolic disorders. These properties make their role crucial from therapeutic and pharmacologic point of views.

The trend of finding the pharmacological activities of the plants of known medicinal uses in folk medicines is quite much effective than going randomly after it $[5,6]$. The genus Euphorbia contributes as the largest amongst the spurge family with over 2000 species, with awesome use value in folk Chinese medicinal system used mainly for skin diseases and edemas [7].

Several species of Euphorbia have been used in local system of medicine; for the treatment of various ailments. Rhizome of Euphorbia neriifolia and aerial parts of Euphorbia royleana has been used for the treatment of anti-inflammatory disorders $[8,9]$. In local system of medicine such as Africa and Australia, Euphorbia hirta has used as a remedy for various ailments especially in hypertension and edema. Previous studies have evaluated E. hirta for antipyretic, analgesic, anti-inflammatory and diuretic activities [10,11]. Strong antioxidant activity of E. macroclada and E. acanthothamnos has been determined in previous studies [12].

Euphorbia dracunculoides Lam., (Euphorbiaceae) is distributed in Southwest Asia, North Africa and South Europe. It is an annual herb and is usually found along riverbanks, in valleys and roadsides of sandy areas in Khyber Pakhtunkhwa Province of Pakistan. Fruits are used to remove warts from skin [13]. Leaves are used in snake bite and epilepsy [14]. A decoction of whole plant is applied on body of cattle for lice killing [15]. Euphorbia dracunculoides has been used by local practitioners for its diuretic and purgative properties. Structurally diversified 19 diterpenoids have been isolated from aerial parts of E. dracunculoides [16]. Because of similar morphology of the dried aerial parts of $E$. drancunculoides to Ruta graveolens, it is sold or used clinically as replacement of $R$. graveolens for analgesic and inflammatory disorders; gout and arthritis $[17,18]$. To our knowledge the scientific validation of $E$. dracunculoides for the use in inflammation related disorders has not been reported earlier. For this purpose we investigated preliminary phytochemical composition, antioxidant and anti-inflammatory activities of various extracts of $E$. dracunculoides. EDEW showed significant antioxidant activity; was subjected to HPLC-DAD analysis for the presence of flavonoid constituents. EDH exhibited remarkable analgesic and anti-inflammatory activities; was explored for GC-MS analysis.

\section{Methods}

\section{Preparation of extract}

Plant was recognized by its local name and collected from the District Lakki Marwat in March 2014. The plant sample after authentication was deposited (Accession No. 127962) at the Herbarium of Pakistan, Quaid-i-Azam University, Islamabad, Pakistan. The fully shade dried aerial parts of $E$. dracunculoides were first powdered followed by two extraction ( $36 \mathrm{~h}$ ) with $\mathrm{n}$-hexane, acetone, ethanol, ethanol + water $(1: 1 \mathrm{v} / \mathrm{v})$ and $95 \%$ methanol in $2: 1$ ratio (v/w). Filtered extracts; EDH, EDA, EDE, EDEW and EDM were dried under vacuum in a rotary evaporator at $40{ }^{\circ} \mathrm{C}$ and stored at $4{ }^{\circ} \mathrm{C}$ for in vitro and in vivo experiments.

\section{Phytochemical analysis}

Different qualitative tests were employed to identify the phytochemical classes present in various extract of the plant E. dracunculoides. 


\section{Assessment of phenols}

For the presence of phenols previously reported methodology was followed [19]. Each sample (1 mg) was suspended in $2 \mathrm{ml}$ of distilled water containing $10 \%$ ferric chloride. The confirmation sign for the presence of phenol was the development of blue or green color.

\section{Assessment of flavonoids}

Protocol of Trease and Evans [20] was followed to establish the presence of flavonoids in each sample. Briefly, $1 \mathrm{mg}$ of each sample was allowed to react with $1 \mathrm{ml}$ of $2 \mathrm{~N}$ sodium hydroxide and appearance of yellow color was considered as the confirmation sign of flavonoid presence.

\section{Assessment of coumarins}

An aliquot of each sample $(1 \mathrm{mg} / \mathrm{ml})$ was mixed with $1 \mathrm{ml}$ of $10 \%$ sodium hydroxide. Appearance of yellow color formation in the test tube was the proof of coumarins presence in test sample [19].

\section{Assessment of saponins}

Each sample $(2 \mathrm{mg})$ was suspended in $2 \mathrm{ml}$ of distilled water and vigorously shaken. The formation of a soapy layer of almost $1-2 \mathrm{~cm}$ was the indication of saponins presence [19].

\section{Assessment of tannins}

Confirmative sign of tannins was the development of dark blue or greenish black color on the mixing of $1 \mathrm{mg}$ of each sample and $2 \mathrm{ml}$ of $5 \%$ ferric chloride [20].

\section{Assessment of terpenoids}

Each sample $0.5 \mathrm{mg}$ was mixed with $2 \mathrm{ml}$ of chloroform and $2 \mathrm{ml}$ of concentrated sulphuric acid. The appearance of a red brown colored layer in the middle of two layers confirmed the existence of terpenoids [20].

\section{Assessment of anthraquinone}

Development of red color was considered as indication for the presence of anthraquinone after mixing of $1 \mathrm{mg}$ of each sample with $2 \mathrm{ml}$ of diluted $2 \%$ hydrochloric acid [19].

\section{Assessment of anthocyanin and betacyanin}

Each sample $(1 \mathrm{mg})$ was boiled for $10 \mathrm{~min}$ in $2 \mathrm{ml}$ of $1 \mathrm{~N}$ sodium hydroxide. Formation of bluish green color was the sign of anthocyanin and yellow color formation of betacyanin presence [20].

\section{Assessment of alkaloids}

An amount of $2 \mathrm{mg}$ of each sample was mixed with concentrated sulphuric acid. The reaction mixture was allowed to react with Mayer's reagent. Appearance of green color or formation of white precipitates was the symbol of alkaloid presence [20].

\section{Quantitative analysis}

Total phenolic as well as flavonoid contents were quantified by the following narrated procedures.

\section{Total phenolic contents (TPC)}

To determine the total phenolic content in each sample spectrophotometric method already reported was followed [21]. Briefly, $1 \mathrm{ml}$ of each sample $(1 \mathrm{mg} / \mathrm{ml})$ was mixed with $9 \mathrm{ml}$ of distilled water and I $\mathrm{ml}$ of FolinCiocalteu reagent. The mixture obtained was mixed rigorously for $5 \mathrm{~min}$ and $10 \mathrm{ml}$ of $7 \% \mathrm{Na}_{2} \mathrm{CO}_{3}$ was added to the mixture. By the addition of distilled water the final volume of mixture was made to $25 \mathrm{ml}$ and was incubated at room temperature for $90 \mathrm{~min}$. Optical density was ensured at wavelength of $750 \mathrm{~nm}$ in triplicate for each sample. By using gallic acid as standard the estimation of TPC was carried out as mg of gallic acid equivalents (GAE) per gram of dry extract/fraction.

\section{Total flavonoid content (TFC)}

To estimate the TFC in the test samples, $0.3 \mathrm{ml}$ of each sample was mixed with $0.15 \mathrm{ml}$ of $0.5 \mathrm{M} \mathrm{NaNO} 2$ followed by the addition of $0.1 \mathrm{ml}$ of $0.3 \mathrm{M} \mathrm{AlCl}_{3} \cdot 6 \mathrm{H}_{2} \mathrm{O}$, and $3.4 \mathrm{ml}$ of $30 \%$ methanol [22]. An aliquot of $1 \mathrm{ml}$ of $1 \mathrm{M} \mathrm{NaOH}$ was added to it after a lapse of $5 \mathrm{~min}$. The optical density of the reaction mixture was recorded at $506 \mathrm{~nm}$ wavelength against the reagent blank. Total flavonoid content as $\mathrm{mg}$ rutin equivalents per gram of dry extract/fraction was estimated while using the calibration curve of rutin.

Gas chromatography-Mass spectrometry (GC-MS) analysis $\mathrm{EDH}$ was analyzed for the presence of active constituents on "Thermo GC-Trace Ultra Ver; 5.0" gas chromatograph coupled with a "Thermo MS DSQ II" for mass determination. Components were separated on a "ZB 5-MS Capillary Standard Non-polar Column" with $60 \mathrm{~m}$ length having $0.25 \mu \mathrm{m}$ film thickness. During the experiment the temperature was raised from 70 to $260{ }^{\circ} \mathrm{C}$ at a rate of $6{ }^{\circ} \mathrm{C} / \mathrm{min}$. The flow rate of the carrier gas; helium was $1 \mathrm{ml} / \mathrm{min}$ while injection volume of the samples was $1 \mu$ l. The identification of chemical constituents was based on comparison of their relative retention times and mass spectra with those obtained from authentic sample and/or the NIST/NBS and Wiley libraries spectra [23].

High performance liquid chromatography (HPLC) analysis On account of significant antioxidant activity for most of the in vitro assays the EDEW extract was selected for HPLC-DAD analysis. HPLC analysis of EDEW was carried out by using HPLC-DAD (Agilent Germany) 
equipment using Sorbex RXC8 (Agilent USA) analytical column with $5 \mu \mathrm{m}$ particle size and $25 \mathrm{ml}$ capacity. Mobile phase was consisted of eluent A, (acetonitrilemethanol-water-acetic acid 15: 10: 85: 1) and eluent B (acetonitrile-methanol-acetic acid/40: 60: 1). The gradient (A: B) utilized was the following: $0-20 \mathrm{~min}$ (0 to $50 \% \mathrm{~B}$ ), 20-25 $\mathrm{min}$ (50 to $100 \% \mathrm{~B}$ ), and then isocratic $100 \% \mathrm{~B}(25-40 \mathrm{~min})$ at flow rate of $1 \mathrm{ml} / \mathrm{min}$. The injection volume of the sample was $20 \mu \mathrm{l}$. Before the injection samples were filtered through $0.45 \mu \mathrm{m}$ membrane filter. Among the standards rutin and gallic acid were analyzed at $257 \mathrm{~nm}$, catechin at $279 \mathrm{~nm}$, caffeic acid at $325 \mathrm{~nm}$ and quercetin, myricetin, kampferol were analyzed at $368 \mathrm{~nm}$ [24]. Each time the column was reconditioned for $10 \mathrm{~min}$ before the next analysis. All samples were assayed in triplicates. Quantification was carried out by the integration of the peak using the external standard method. All chromatographic operations were carried out at an ambient temperature.

\section{In vitro antioxidant assays}

The in vitro antioxidant assays were carried out by preparing the plant samples $(1 \mathrm{mg} / \mathrm{ml})$ in $95 \%$ methanol and then making its serial dilutions. The specific protocol was followed for finding specific scavenging activities of the plant samples.

\section{DPPH (1, 1-diphenyl-2-picryl-hydrazyl) radical scavenging assay}

The DPPH scavenging capabilities of deleterious effects of free radical were determined by following the methodology of [25]. An amount of $24 \mathrm{mg}$ of DPPH was dissolved in $100 \mathrm{ml}$ methanol and the stock solution was kept at $20{ }^{\circ} \mathrm{C}$ temperature for further use. The optical density of DPPH was optimized at $0.908( \pm 0.02)$ at $517 \mathrm{~nm}$ by diluting the pre made DPPH stock solution with methanol. An aliquot of $3 \mathrm{ml}$ of DPPH was mixed with $100 \mathrm{ml}$ plant samples with different concentrations $(25-250 \mu \mathrm{g} / \mathrm{ml})$. Following continuous stirring the test tubes were incubated for $15 \mathrm{~min}$ at room temperature. Optical density was recorded at wavelength of $517 \mathrm{~nm}$. Ascorbic acid was used as standard to compare the antioxidant activity. Antioxidant capacity was determined by the following equation:

$$
\begin{aligned}
\text { Inhibition } \%= & {\left[\frac{\text { Absorbance of control-Absorbance of the sample }}{\text { Absorbance of control }}\right] } \\
& \times 100
\end{aligned}
$$

\section{Hydroxyl radical scavenging assay}

The power of scavenging hydroxyl free radicals refers to the antioxidant potential of plant samples using methodology practiced by [26]. This technique involved the mixing of $500 \mu \mathrm{l}$ of 2-deoxyribose $(2.8 \mathrm{mM})$ prepared in
$50 \mathrm{mM}$ phosphate buffer and its $\mathrm{pH}$ was maintained at 7.4. The reaction mixture was prepared by addition of $100 \mu \mathrm{l}$ of $0.1 \mathrm{M}$ EDTA, $200 \mu \mathrm{l}$ of ferric chloride $(100 \mathrm{mM})$ and $100 \mu \mathrm{l}$ of $200 \mathrm{mM} \mathrm{H}_{2} \mathrm{O}_{2}$ and $100 \mu \mathrm{l}$ of plant sample.

The initiation of reaction was brought by the introduction of $100 \mu \mathrm{l}$ of ascorbic acid (300 mM) and incubated for $1 \mathrm{~h}$ at $37{ }^{\circ} \mathrm{C}$. Then $1 \mathrm{ml}$ of $2.8 \%$ trichloroacetic acid and $1 \mathrm{ml}$ of $1 \% \mathrm{w} / \mathrm{v}$ thiobarbituric acid prepared in $50 \mathrm{mM} \mathrm{NaOH}$ were added to the reaction mixture. The whole recipe was heated in water bath for $15 \mathrm{~min}$. After cooling to room temperature the absorbance of the reaction mixture was recorded at $532 \mathrm{~nm}$. The hydroxyl radical scavenging activity was analyzed by the following formula:

Scavenging effect $\%=\left[\frac{1-\text { Absorbance of the sample }}{\text { Absorbance of control }}\right] \times 100$

\section{Nitric oxide scavenging assay}

The method of Bhaskar and Balakrishnan [27] was used to assess the nitric oxide scavenging potential of the plant samples. The Griess reagent was prepared by adding equimolar quantity of $0.1 \%$ napthylenediamine in distilled water and $1 \%$ of sulphanilamide in $5 \%$ phosphoric acid. A volume of $100 \mu \mathrm{l}$ of sample was added to $100 \mu \mathrm{l}$ of sodium nitroprusside $(10 \mathrm{mM})$ being prepared in saline phosphate buffer. An aliquot of $1 \mathrm{ml}$ of the Griess reagent was added to the reaction mixture. After incubation at room temperature for $3 \mathrm{~h}$ the optical density of the reaction mixture was noted spectrophotometrically at $546 \mathrm{~nm}$ using ascorbate as a positive control. Following formula was used for determining the percentage inhibition of nitric oxide radical formation.

$$
\begin{aligned}
\text { Inhibition } \%= & {\left[\frac{\text { Absorbance of control-Absorbance of the sample }}{\text { Absorbance of control }}\right] } \\
& \times 100
\end{aligned}
$$

\section{Chelating power assay}

The iron (II) binding capability at multiple sites confers the antioxidant potential of plant samples [28]. The plant sample with its serial dilutions was prepared in methanol and $200 \mu \mathrm{l}$ of each dilution was mixed with $900 \mu \mathrm{l}$ of methanol and $100 \mu \mathrm{l} \mathrm{FeCl}_{2} \cdot 2 \mathrm{H}_{2} \mathrm{O}(2.0 \mathrm{mM})$ and incubated for $5 \mathrm{~min}$. The reaction was initiated by introducing $400 \mu \mathrm{l}$ of ferrozine $(5.0 \mathrm{mM})$. After incubation for $10 \mathrm{~min}$ the optical density was recorded at $562 \mathrm{~nm}$ using EDTA as standard in comparison. The chelating power was determined by the following formula: 


$$
\begin{aligned}
\text { Chelating effect } \%= & {\left[\frac{\text { Absorbance of control-Absorbance of the sample }}{\text { Absorbance of control }}\right] } \\
& \times 100
\end{aligned}
$$

\section{$\beta$-Carotene bleaching assay}

Inhibition ability of $\beta$-carotene bleaching was recorded by the method of [29]. The reagent was prepared by dissolving $2 \mathrm{mg}$ of $\beta$-carotene in $10 \mathrm{ml}$ of chloroform followed by addition of $200 \mathrm{mg}$ of Tween 80 and $20 \mathrm{mg}$ of linoleic acid. After evaporation of chloroform, $50 \mathrm{ml}$ of distilled water was added to the reaction mixture and vigorously vortexed to get a uniform emulsion of $\beta$ carotene linoleate. In freshly prepared $250 \mu \mathrm{l}$ of emulsion, $30 \mu \mathrm{l}$ of plant sample was added and optical density was measured at $470 \mathrm{~nm}$ at $0 \mathrm{~h}$. Then after keeping the reaction mixture at $45{ }^{\circ} \mathrm{C}$ for $2 \mathrm{~h}$ the final optical density was again recorded. Catechin was served as standard in this assay and $\%$ inhibition of $\beta$-carotene was determined by the formula:

$$
\% \text { inhibition }=\left[\left(\mathrm{A}_{\mathrm{A}(120)}-\mathrm{A}_{\mathrm{C}(120)}\right) /\left(\mathrm{A}_{\mathrm{C}(0)}-\mathrm{A}_{\mathrm{A}(120)}\right)\right] \times 100
$$

Where $A_{A}(120)$ is the absorbance of the antioxidant at $t=120 \mathrm{~min}, \mathrm{~A}_{C}(120)$ is the absorbance of the control at $t=120 \mathrm{~min}$, and $\mathrm{A}_{\mathrm{C}}(0)$ is the absorbance of the control at $\mathrm{t}=0 \mathrm{~min}$.

\section{Reducing power assay}

Reducing power of various extracts was estimated by the method of $[30,31]$. Briefly, $2 \mathrm{ml}$ of plant extract was mixed with $2 \mathrm{ml}$ of $0.2 \mathrm{M}$ phosphate buffer (pH 6.6) and $2 \mathrm{ml}$ of potassium ferricyanide $(10 \mathrm{mg} / \mathrm{l})$ and the reaction mixture was incubated at $50{ }^{\circ} \mathrm{C}$ for $20 \mathrm{~min}$. After addition of $2 \mathrm{ml}$ of trichloroacetic acid $(100 \mathrm{mg} / \mathrm{l})$ in the reaction mixture, $2 \mathrm{ml}$ was of it was diluted with $2 \mathrm{ml}$ of distilled water and $0.4 \mathrm{ml}$ of $\mathrm{FeCl}_{3}(0.1 \%)$. Optical density of the reaction mixture was measured at $700 \mathrm{~nm}$ after 10 min of incubation. Gallic acid was used as standard.

\section{Phosphomolybedenum assay}

The methodology of [31] was used to assess the antioxidant capabilities of the plant sample. Accordingly, $0.1 \mathrm{ml}$ of the plant sample was mixed with $1 \mathrm{ml}$ of the reagent solution (prepared by adding $28 \mathrm{mM} \mathrm{Na}_{3} \mathrm{PO}_{4}$ and $0.6 \mathrm{M}$ $\mathrm{H}_{2} \mathrm{SO}_{4}$ with that of $4 \mathrm{mM}$ ammonium molybdate). After incubation at $95{ }^{\circ} \mathrm{C}$ in a water bath for 90 min the reaction mixture was cooled down to room temperature and optical density was recorded at $765 \mathrm{~nm}$. Ascorbic acid served as standard in this assay.

\section{Anti-inflammatory activity}

Protocol of [32] was followed to estimate the antiinflammatory activity of extracts by carrageenan-induced paw edema in rat. Sprague-Dawley rats (six weeks old) weighing about 150-200 g were randomly divided into six groups containing 6 rats in each group. Rats had free access to the laboratory feed and water. National institute of health $(\mathrm{NIH})$ guidelines were strictly carried out using test animals for experimentation. Ethical Committee of Quaid-i-Azam University Islamabad approved the study protocol (Bch\#0267) for the animal care and experimentation. Group I was negative control and received DMSO, Group II orally received $10 \mathrm{mg} / \mathrm{kg}$ of drug diclofenac sodium (1:1 W/V DMSO). Group III to Group VII were given $300 \mathrm{mg} / \mathrm{kg}$ dose of EDH, EDA, EDE, EDEW and EDM respectively. To develop the paw edema, $1 \mathrm{ml} / \mathrm{kg}$ body weight of carrageenan solution $(0.9 \% \mathrm{w} / \mathrm{v}$; saline) was injected in the right paw of each rat after $1 \mathrm{~h}$ of the administration of plant sample. Paw volume was measured plethysmographically at 0 , 1st, 2nd, 3rd and 4th $\mathrm{h}$ after carrageenan injection and the following formulae for calculating percent inhibition of edema were used;

$$
\mathrm{EV}=\mathrm{PVA}-\mathrm{PVI}
$$

Where, EV = Edema volume, PVI = Paw volume before carrageenan administration (i.e. initial paw volume) and, PVA = Paw volume after carrageenan administration.

$$
\text { Percent inhibition }=\left[\frac{(\mathrm{EVc}-\mathrm{EVt})}{(\mathrm{EVc})} \times 100\right]
$$

$\mathrm{EVc}=$ Edema volume of control animals, EVt $=$ Edema volume of test sample animals.

\section{Analgesic activity}

The procedure described by [33], was followed to perform this test. Sprague-Dawley rats of either sex $(n=6)$ weighing 180-220 g were used. Animals were subjected to pre-testing on a hot plate analgesimeter (Harvard apparatus Ltd., UK) maintained at $55 \pm 0.1{ }^{\circ} \mathrm{C}$. Animals having latency time greater than $15 \mathrm{~s}$ on hot plate during pre-testing were excluded. Animals were divided randomly into 7 groups, each consisting of six rats. Group I was negative control and received $2 \mathrm{ml} / \mathrm{kg}$ p.o. DMSO, Group II received $10 \mathrm{mg} / \mathrm{kg}$ i.p. of the standard drug morphine sulphate. Group III to Group VII were given $300 \mathrm{mg} / \mathrm{kg}$ p.o. dose of EDH, EDA, EDE, EDEW and EDM respectively. The latency time was recorded for each group at $0,30,60$ and 90 min following drug administration. In order to prevent the tissue damage the cut off time of $30 \mathrm{~s}$ was set for all animals. Percent analgesia was calculated using the following formula. 
$\%$ Analgesia $=\left[\frac{(\text { Test latency }- \text { control latency })}{(\text { Cut off time- } \text { control latency })} \times 100\right]$

\section{Statistical analysis}

Data obtained in this study was presented as mean \pm SD . One way analysis of variance was performed to determine the variability among groups by Statistix 8.1. GraphPad Prim 5 was used to determine the correlation of $\mathrm{IC}_{50}$ values of antioxidant assays with TPC and TFC by Pearson's correlation coefficient. Significant differences among groups were calculated by Tukey's multiple comparison tests. Statistical significance was set at $P>0.05$.

\section{Results}

\section{Extraction yield, total phenolic and flavonoid content}

By using $100 \mathrm{~g}$ of dry powder of $E$. dracunculoides for extraction, the maximum yield $5462 \mathrm{mg}$ powder was obtained for EDEW followed by $1703 \mathrm{mg}$ (EDM), $1340 \mathrm{mg}$ (EDA), $724 \mathrm{mg}$ (EDE) and $592 \mathrm{mg}(\mathrm{EDH})$. On the basis of standard regression lines for gallic acid $(y=$ $\left.0.0103 x+0.1875 ; R^{2}=0.9978\right)$ and rutin $(y=0.00028 x+$ 0.497; $\left.R^{2}=0.998\right)$, the equivalents of TPC and TFC were calculated (Table 1). EDEW showed maximum quantity of TPC (17.35 $\pm 0.62 \mathrm{mg}$ GAE/g dry sample) followed by EDE (16.41 $\pm 0.54 \mathrm{mg}$ GAE/g dry sample), EDM (14.11 \pm $0.37 \mathrm{mg}$ GAE$/ \mathrm{g}$ dry sample), EDA (10.62 $\pm 0.33 \mathrm{mg} \mathrm{GAE} / \mathrm{g}$ dry sample) and EDH ( $8.21 \pm 0.49 \mathrm{mg} \mathrm{GAE} / \mathrm{g}$ dry sample). Flavonoids were found to be rich in EDEW $(7.57 \pm 0.42 \mathrm{mg}$ $\mathrm{RE} / \mathrm{g}$ dry sample) followed by EDE $(6.77 \pm 0.31 \mathrm{mg} R E / \mathrm{g}$ dry sample), EDM $(4.84 \pm 0.29 \mathrm{mg} R E / g$ dry sample), EDA $(4.52 \pm 0.37 \mathrm{mg} \mathrm{RE} / \mathrm{g}$ dry sample) and EDA $(4.18 \pm 0.25 \mathrm{mg}$ $\mathrm{RE} / \mathrm{g}$ dry sample).

\section{Phytochemical classes}

The results of phytochemical analysis of all the extracts of $E$. dracunculoides are listed in Table 2. Qualitative analysis of $E$. dracunculoides ensured the presence of tannins, phenols, flavonoids and coumarins in all extracts of $E$. dracunculoides except coumarins were absent in EDH. Presence of anthraquinones was not recorded in all the extracts. EDEW contained the
Table 2 Phytochemical analysis of E. dracunculoides

\begin{tabular}{llllll}
\hline Phytochemical & EDH & EDA & EDE & EDEW & EDM \\
\hline Terpenoids & ++ & - & - & + & - \\
Coumarins & - & + & ++ & +++ & +++ \\
Flavonoids & + & + & +++ & +++ & ++ \\
Tannins & + & ++ & ++ & +++ & +++ \\
Anthraquinones & - & - & - & - & - \\
Phenols & + & + & +++ & +++ & ++ \\
Alkaloids & + & - & - & ++ & ++ \\
Saponins & - & - & - & ++ & - \\
Betacyanin & - & - & + & ++ & ++ \\
\hline
\end{tabular}

(+) present, $(-)$ absent, (++) moderate concentration, (+++) abundant concentration $E D H E$. dracunculoides n-hexane extract, EDA E. dracunculoides aqueous extract, $E D E$ E. dracunculoides ethyl acetate, EDEW E. dracunculoides ethyl acetate + water extract, EDM E. dracunculoides methanol extract

maximum phytochemical classes and EDA showed the least number of existent phytochemical classes.

\section{GC-MS analysis of $\mathbf{n}$-hexane extract}

The $n$-hexane extract of $E$. dracunculoides was selected for GC-MS analysis due to its significant analgesic and anti-inflammatory activities. GC-MS analysis indicated that EDH contained 30 chemical constituents eluted between 6.36 and $40.10 \mathrm{~min}$ (Fig. 1). The identification of chemical constituents was based on comparison of their relative retention times and mass spectra with those obtained from authentic sample and/or the NIST/NBS and Wiley libraries spectra (Table 3). Of these 30 chemical constituents, there were 7 terpenoides $(13.25 \%$ on the basis of peak area), 4 lactones (2.12 \%), 3 steroids (2.59\%), 3 phenols (1.60 \%), 2 hetrocycles (73.91\%), 1 fatty acid (2.63\%), 1 ester (1.30\%), 1 carboxylic acid $(0.58 \%), 1$ lactam $(0.51 \%), 1$ nitrile $(0.40 \%), 1$ alkyne (0.36 \%), 1 hydrazone (0.19\%), 1 terpene $(0.18 \%), 1$ aldehyde $(0.14 \%), 1$ ketone $(0.13 \%)$ and 1 amino acid (0.1\%) in EDH.

\section{HPLC-DAD analysis of ethanol + water extract}

HPLC-DAD profile of EDEW was illustrated in Fig. 2. EDEW showed the existence of rutin, catechin, caffeic

Table 1 Extraction yield, total phenolic and flavonoid contents of E. dracunculoides

\begin{tabular}{llll}
\hline Extract & Yield (mg/100 g powder) & $\begin{array}{l}\text { Total phenolic content (mg gallic acid } \\
\text { equivalent/ g dry sample) }\end{array}$ & $\begin{array}{l}\text { Total flavonoid content } \\
\text { (mg rutin equivalent/ g dry sample) }\end{array}$ \\
\hline EDH & 592 & $8.21 \pm 0.49^{\mathrm{e}}$ & $4.18 \pm 0.25^{\mathrm{e}}$ \\
EDA & 1,340 & $10.62 \pm 0.33^{\mathrm{d}}$ & $4.52 \pm 0.37^{\mathrm{d}}$ \\
EDE & 724 & $16.41 \pm 0.54^{\mathrm{b}}$ & $6.77 \pm 0.31^{\mathrm{b}}$ \\
EDEW & 5,462 & $17.35 \pm 0.62^{\mathrm{a}}$ & $7.57 \pm 0.42^{\mathrm{a}}$ \\
EDM & 1,703 & $14.11 \pm 0.37^{\mathrm{c}}$ & $4.84 \pm 0.29^{\mathrm{c}}$ \\
\hline
\end{tabular}

EDH E. dracunculoides n-hexane extract, EDA E. dracunculoides aqueous extract, EDE E. dracunculoides ethyl acetate, EDEW E. dracunculoides ethyl acetate + water extract, EDM E. dracunculoides methanol extract. Each value is represented as mean \pm SD $(n=3)$. Means with different superscript $\left.{ }^{a-e}\right)$ letters in the column are significantly $(P<0.05)$ different from one another 


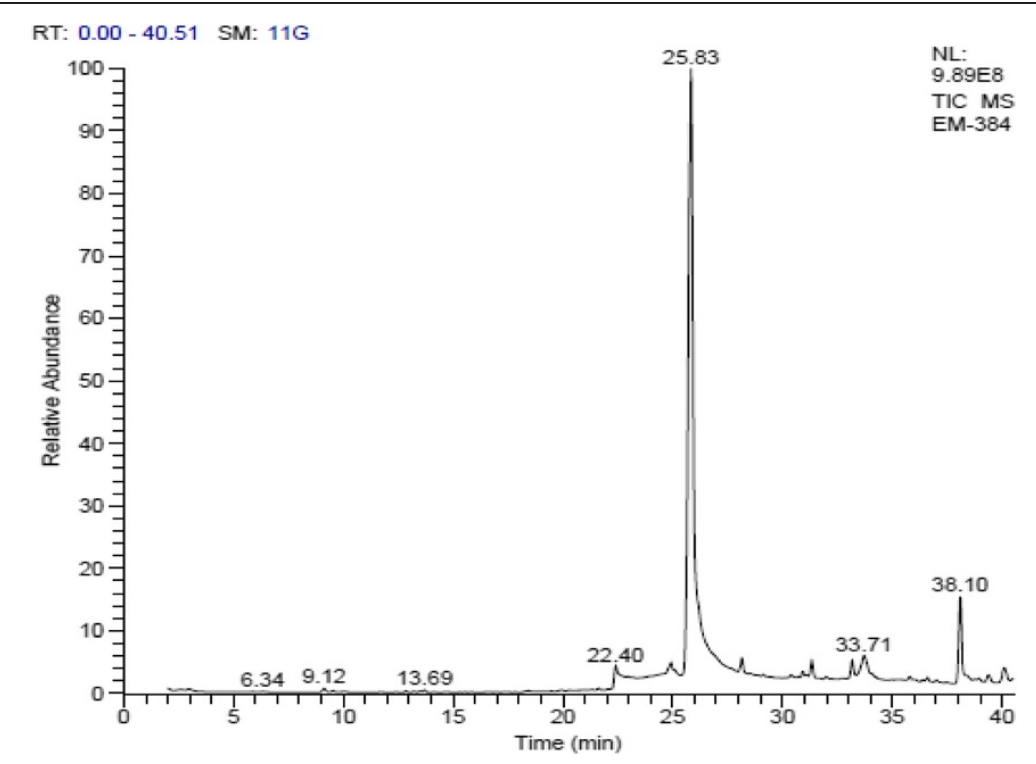

Fig. 1 GC-MS analysis of $n$-hexane extract of E. dracunculoides

acid and myricetin. Rutin showed maximum quantity $(65.8 \pm 2.2 \mu \mathrm{g} / \mathrm{mg}$ dry extract) followed by catechin $(15.3 \pm$ $1.2 \mu \mathrm{g} / \mathrm{mg}$ dry extract), caffeic acid $(8.5 \pm 0.75 \mu \mathrm{g} / \mathrm{mg}$ dry extract) and myricetin $(4.54 \pm 0.35 \mu \mathrm{g} / \mathrm{mg}$ dry extract $)$ as demonstrated in Table 4.

\section{In vitro antioxidant activities \\ $D P P H$ radical scavenging activity}

Moderate to low scavenging activity for DPPH was exhibited by all the extracts of E. dracunculoides (Table 5). Minimum $\mathrm{IC}_{50}$ values were exhibited by EDEW (144.7 \pm $3.4 \mu \mathrm{g} / \mathrm{ml})$ followed by $\operatorname{EDE}(263.6 \pm 3.7 \mu \mathrm{g} / \mathrm{ml})$ and EDM $(351.3 \pm 4.5 \mu \mathrm{g} / \mathrm{ml})$ while EDA and EDH showed the higher $\mathrm{IC}_{50}$ values $(>1000 \mu \mathrm{g} / \mathrm{ml})$. Overall, order of $\mathrm{IC}_{50}$ of $\mathrm{EDEW}<\mathrm{EDE}<\mathrm{EDM}<\mathrm{EDA}<\mathrm{EDH}$ was observed. The DPPH radical scavenging activity of extract/ fractions showed significant correlation with TPC $\left(\mathrm{R}^{2}=\right.$ 0.9028, $P<0.01)$ and non-significant with TFC $\left(\mathrm{R}^{2}=\right.$ $0.5687, P>0.05$, Table 6). All the extracts showed the higher $\mathrm{IC}_{50}$ values than ascorbic acid $(26.65 \pm 2.4 \mu \mathrm{g} / \mathrm{ml})$. However, concentration dependent activity was recorded for all the extracts.

\section{Hydroxyl radical $(\cdot \mathrm{OH})$ scavenging assay}

All the extracts of E. dracunculoides scavenged $\bullet \mathrm{OH}$ radicals and prevented 2-deoxyribose breakdown (Table 5). A concentration-dependent pattern was observed for hydroxyl radical scavenging activity. Lowest $\mathrm{IC}_{50}$ values were recorded for EDEW $(78.02 \pm 1.21 \mu \mathrm{g} / \mathrm{ml})$ followed by EDE $(121.70 \pm 2.05 \mu \mathrm{g} / \mathrm{ml}), \operatorname{EDM}(142.43 \pm 2.51 \mu \mathrm{g} / \mathrm{ml})$, EDA $(202.20 \pm 3.4 \mu \mathrm{g} / \mathrm{ml})$ and EDA $(297.12 \pm 3.22 \mu \mathrm{g} / \mathrm{ml})$. $\mathrm{IC}_{50}$ values of EDH, EDA, EDE, EDEW and EDM were significantly higher from rutin $(80.74 \pm 2.25 \mu \mathrm{g} / \mathrm{ml})$ and gallic acid $(45.97 \pm 1.92 \mu \mathrm{g} / \mathrm{ml})$. Significant correlation of $\mathrm{IC}_{50}$ values of hydroxyl radical scavenging was determined for TPC $\left(R^{2}=0.9505, P<0.01\right)$ as well as for TFC $\left(R^{2}=\right.$ 0.7224, $P<0.05$ ) (Table 6).

\section{Nitric oxide $\left(\mathrm{NO}^{-}\right)$scavenging assay}

In the present study, moderate level of nitric oxide scavenging activity was observed for all the extracts with $\mathrm{IC}_{50}$ values for EDEW $(317.8 \pm 3.35 \mu \mathrm{g} / \mathrm{ml})$, EDE (366.81 \pm $3.12 \mu \mathrm{g} / \mathrm{ml})$ and EDM $(405.01 \pm 3.57 \mu \mathrm{g} / \mathrm{ml})$ as compared to standard ascorbic acid $(244.45 \pm 2.35 \mu \mathrm{g} / \mathrm{ml})$. $\mathrm{IC}_{50}$ values for other extracts were $583.4 \pm 3.65 \mu \mathrm{g} / \mathrm{ml}$ and $756.31 \pm 4.23 \mu \mathrm{g} / \mathrm{ml}$ for EDA and $\mathrm{EDH}$, respectively (Table 5). $\mathrm{IC}_{50}$ values obtained for nitric oxide scavenging activity exhibited a significant correlation with TPC $\left(\mathrm{R}^{2}=\right.$ $0.9638, P<0.01)$ and TFC $\left(\mathrm{R}^{2}=0.6822, P<0.05\right)$ (Table 6).

\section{Iron chelating activity}

Iron chelating activity ( $\mathrm{IC}_{50}$ values) of $E$. dracunculoides extracts are given in Table 5. In current study, the best $\mathrm{IC}_{50}$ values for iron chelation were exhibited by EDE $(279.51 \pm 2.57 \mu \mathrm{g} / \mathrm{ml})$ while the least by EDH $(616.57 \pm$ $3.3 \mu \mathrm{g} / \mathrm{ml}) . \mathrm{IC}_{50}$ value for other extracts was; EDEW $(331.46 \pm 2.42 \mu \mathrm{g} / \mathrm{ml}), \operatorname{EDM}(446.3 \pm 3.52 \mu \mathrm{g} / \mathrm{ml})$ and EDA $(531.43 \pm 2.94 \mu \mathrm{g} / \mathrm{ml}) . \mathrm{IC}_{50}$ of standard EDTA was $189.85 \pm 1.53 \mu \mathrm{g} / \mathrm{ml}$ (Table 5). Significant correlation $\left(\mathrm{R}^{2}=0.9361, P<0.01\right)$ of $\mathrm{IC}_{50}$ values was observed with TFC $\left(\mathrm{R}^{2}=0.9361, P<0.01\right)$ and for TPC $\left(\mathrm{R}^{2}=\right.$ 0.8232, $P<0.05$ ) (Table 6 ).

\section{$\beta$-Carotene scavenging activity}

Ethanol + water extract of $E$. dracunculoides (EDEW) showed the lowest $\mathrm{IC}_{50}$ value $(100.40 \pm 1.8 \mu \mathrm{g} / \mathrm{ml})$ as 
Table 3 GC-MS analysis of EDH

\begin{tabular}{|c|c|c|}
\hline S. No & Compound name & Type \\
\hline 1 & O,N-Permethylated N-Acetyllysine & Amino acid \\
\hline 2 & Phenol, 2-Methyl-5-(1-Methylethyl)- & Phenol \\
\hline 3 & 2,4-Decadienal, (E,E)- (Cas) & Aldehyde \\
\hline 4 & Phenol, 2-Methoxy-4-(2-Propenyl)- (Cas) & Phenol \\
\hline 5 & $\begin{array}{l}\text { 3,4-Dihydro-2H-1,5-(3"-t-butyl) } \\
\text { benzodioxepine }\end{array}$ & Heterocycle \\
\hline 6 & 4-(Phenylethynyl)-1-methoxybenzene & Alkyne \\
\hline 7 & (-)-Loliolide & Lactone \\
\hline 8 & 2-Pentadecanone, 6,10,14-trimethyl- & Terpenoid \\
\hline 9 & $(\mathrm{E}, \mathrm{E})$-Farnesyl Acetone & Terpenoid \\
\hline 10 & Hexadecanoic acid, methyl ester (CAS) & Terpenoid \\
\hline 11 & Hexadecanoic acid (CAS) & Fatty acid \\
\hline 12 & Hexadecanoic acid, ethyl ester & Terpenoid \\
\hline 13 & $\begin{array}{l}\text { 9,12,15-Octadecatrienoic acid, methyl ester, } \\
(\mathrm{Z}, \mathrm{Z}, \mathrm{Z}) \text {-(CAS) }\end{array}$ & Terpenoid \\
\hline 14 & 1H-Imidazole, 1-ethyl- (CAS) & Heterocycle \\
\hline 15 & $\begin{array}{l}\text { 3-(2-Methylaminophenyl)-1H-benzopyran-1- } \\
\text { one }\end{array}$ & Lactone \\
\hline 16 & 4,8,12,16-Tetramethylheptadecan-4-olide & Lactone \\
\hline 17 & $\begin{array}{l}\text { Estra-1,3,5(10)-trien-17-one, 3-hydroxy-2- } \\
\text { methoxy- }\end{array}$ & Steroid \\
\hline 18 & 3à,6á-Dihydroxyandrost-4-Ene-17-One & Steroid \\
\hline 19 & Di-(2-ethylhexyl)phthalate & Ester \\
\hline 20 & 10-Methylundeca-2,4,8-triene & Terpene \\
\hline 21 & Austrobailignan-6 & Phenol \\
\hline 22 & Butyl 9,12,15-octadecatrienoate & Terpenoid \\
\hline 23 & $\begin{array}{l}\text { 1,7,7-trimethyl-3-thiocyanatomethylen- } \\
\text { bicyclo[2,2,1]hepta }\end{array}$ & Ketone \\
\hline 24 & $\begin{array}{l}\text { 2-Acetamido-3-(3,4-dihydroxyphenyl) } \\
\text { propenoic acid }\end{array}$ & $\begin{array}{l}\text { Carboxylic } \\
\text { acid }\end{array}$ \\
\hline 25 & $\begin{array}{l}\text { 2,7-Diphenyl-1,6-dioxopyridazino[4,5-2',3'] } \\
\text { pyrrolo[4,'5'-D pyridazine }\end{array}$ & Lactam \\
\hline 26 & $\begin{array}{l}\text { 4-(cis-6-Methoxymethyl-3,4-dimethyl-3- } \\
\text { cyclohexenyl)-trans-3-buten-2-one 2,4- } \\
\text { dinitrophenylhydrazone }\end{array}$ & Hydrazone \\
\hline 27 & 1-Heneicosyl formate & Terpenoid \\
\hline 28 & 2-Methoxy-6-hydroxy-1,3-dicyanoazulene & Nitrile \\
\hline 29 & Xanthinin & Lactone \\
\hline 30 & Stigmasta-5,22-dien-3-ol, (3á,22E)- (CAS) & Steroid \\
\hline
\end{tabular}

compared to other extracts viz. EDE $(120.53 \pm 2.52 \mu \mathrm{g} /$ $\mathrm{ml})$, EDM $(210.23 \pm 3.41 \mu \mathrm{g} / \mathrm{ml})$ and EDA $(181.10 \pm$ $1.9 \mu \mathrm{g} / \mathrm{ml}$ ). However, the maximum $\mathrm{IC}_{50}$ was shown by EDH $(244.06 \pm 3.8 \mu \mathrm{g} / \mathrm{ml})$ as compared to the standard catechin $(78.57 \pm 2.15 \mu \mathrm{g} / \mathrm{ml})$ shown in Table 5 . The concentration dependent inhibition in $\beta$-carotene bleaching power pattern was observed for all the extracts. The assay showed significant correlation of $\mathrm{IC}_{50}$ with both
TPC $\left(\mathrm{R}^{2}=0.7579, P<0.05\right)$ and TFC $\left(\mathrm{R}^{2}=0.8965, P<0.01\right)$ as shown in Table 6.

\section{Reducing power assay}

Ethanol + water extract (EDEW) showed the highest reducing power with $792.59 \mathrm{mg}$ ascorbic acid equivalent/g sample measured at $250 \mu \mathrm{g} / \mathrm{ml}$ of extract followed by EDE (777.77 mg ascorbic acid equivalents/g sample), EDM (770.37 mg ascorbic acid equivalents/g sample), EDA (711.11 mg ascorbic acid equivalents/g sample) and EDH (688.88 $\mathrm{mg}$ ascorbic acid equivalents/g sample) as shown in Fig. 3. There was recorded a significant correlation between the reducing power and with both TPC $\left(R^{2}=0.9812, P<0.01\right)$ and TFC $\left(R^{2}=0.7349, P<0.05\right)$ shown in Table 6.

\section{Total antioxidant capacity (phosphomolybdenum assay)}

Total antioxidant capacity of various extracts was determined by phosphomolybdate method and expressed as equivalents of ascorbic acid (mg/g of extract) as shown in Fig. 4. Total antioxidant capacity was found to decrease in the order, EDEW $>$ EDE $>$ EDM $>$ EDA $>$ EDH. All the samples exhibited an increase in antioxidant capacity with increase in concentration. The assay showed significant correlation with TPC $\left(R^{2}=0.7429, P<0.05\right)$ and TFC $\left(\mathrm{R}^{2}=0.893, P<0.01\right)$ as shown in Table 6 .

\section{Anti-inflammatory activity of $E$. dracunculoides}

The results of carrageenan-induced rat paw edema are summarized in Table 7. EDH, EDA, EDE, EDEW and EDM of E. dracunculoides were tested for their antiinflammatory effects. The results obtained indicated that EDH possessed significant $(P<0.05)$ anti-inflammatory activity in rats followed by EDE and EDEW. The EDH at the test dose i.e. $300 \mathrm{mg} / \mathrm{kg}$ body weight reduced the carrageenan-induced edema up to $68.660 \pm 10.502 \%$ whereas the standard drug diclofenac sodium showed $78.823 \pm 6.395 \%$ of edema inhibition after $4 \mathrm{~h}$ of carrageenan injection. Similarly EDE and EDEW showed $51.384 \pm 8.623 \%$ and $46.302 \pm 8.975 \%$ inhibition of edema formation after $4 \mathrm{~h}$ of carrageenan administration.

\section{Analgesic activity of $E$. dracunculoides}

In this assay $E$. dracunculoides extracts; EDH, EDA, EDE, EDEW and EDM were evaluated in rats for their analgesic potential in hot plate test (Table 8). All the extracts showed increase in the percent latency period with the maximum was recorded with $74.309 \pm 5.864 \%$ for $\mathrm{EDH}$ as compared to $78.889 \pm 5.853 \%$ with morphine after $60 \mathrm{~min}$ of drug administration. The EDE and EDM also exhibited more than $50 \%$ of analgesia. The extracts and the standard drug showed less analgesia after 90 min of drug administration except the EDA and 


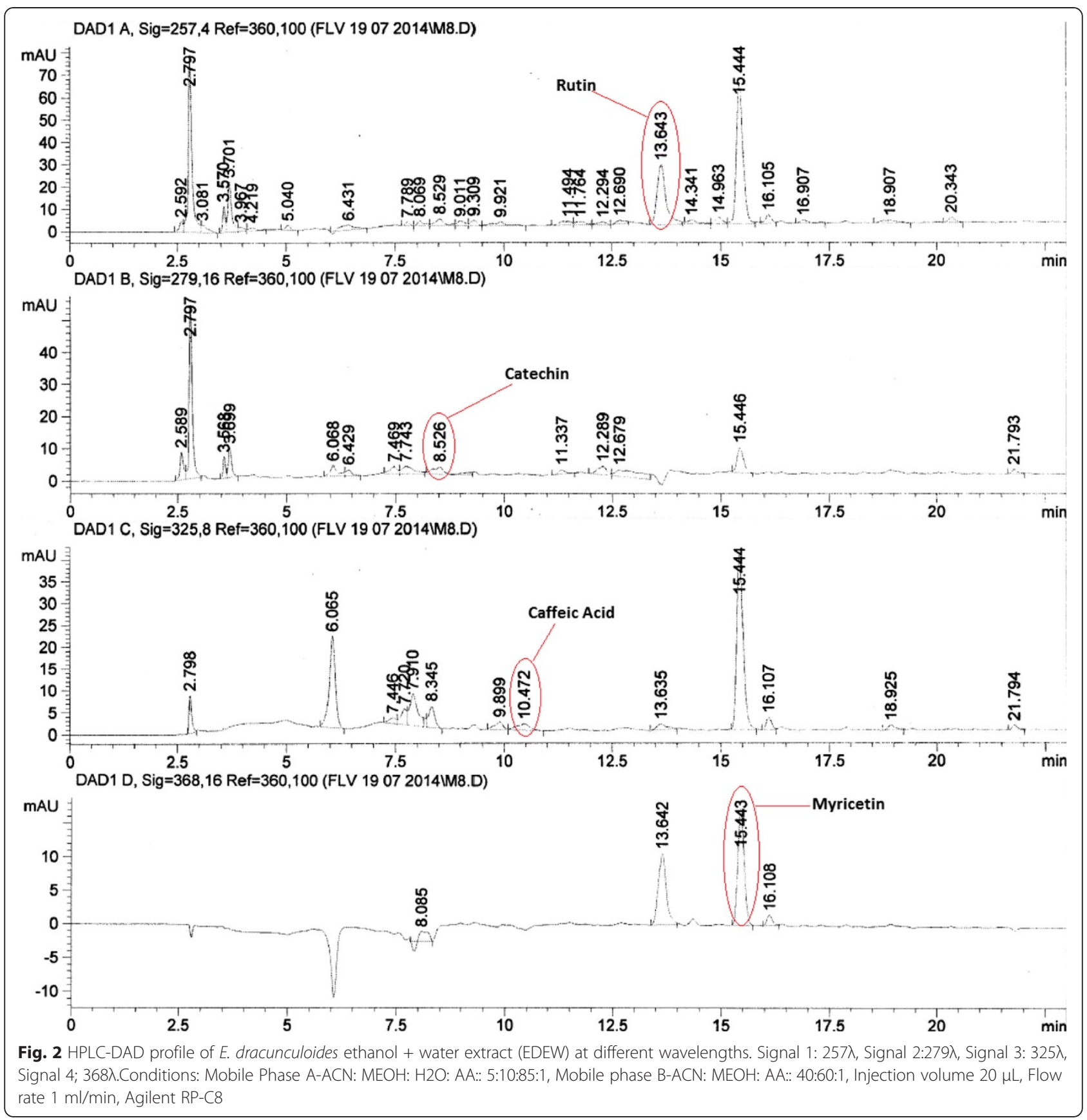

Table 4 HPLC-DAD results for EDEW of $E$. dracunculoides

\begin{tabular}{lll}
\hline Flavonoid/Phenolics & Signal wavelength & Quantity $(\mu \mathrm{g} / \mathrm{mg}$ dry extract) \\
\hline Rutin & 257 & $65.8 \pm 2.2$ \\
Catechin & 279 & $15.3 \pm 1.2$ \\
Caffeic acid & 325 & $8.5 \pm 0.75$ \\
Myricetin & 368 & $4.54 \pm 0.35$ \\
\hline
\end{tabular}

EDEW ethanol + water extract. Each value is represented as mean $\pm \mathrm{SD}(n=3)$
EDEW where more analgesia was recorded after $90 \mathrm{~min}$ of drug administration.

\section{Discussion}

The role of medicinal plants in curing diseases is increasing due to the presence of versatile compounds that have the ability to cure a variety of diseases and helping physicians to cope with increasing ratio of ailments these days [34]. Plants are rich in variety of compounds with different polarities [35]. Maximum yield was obtained in EDEW followed by EDM and the minimum yield was 
Table $\mathbf{5} I C_{50}$ values of different antioxidant activities of $E$. dracunculoides extracts

\begin{tabular}{|c|c|c|c|c|c|}
\hline \multicolumn{6}{|l|}{$\mathrm{IC}_{50}(\mu \mathrm{g} / \mathrm{ml})$} \\
\hline Plant sample & DPPH scavenging & Hydroxyl scavenging & Nitric Oxide & $\beta$-Carotene & Iron chelating \\
\hline EDH & $>1000$ & $297.12 \pm 3.22^{\mathrm{a}}$ & $756.31 \pm 4.23^{a}$ & $244.06 \pm 3.81^{a}$ & $616.57 \pm 3.33^{\mathrm{a}}$ \\
\hline EDA & $>1000$ & $202.20 \pm 3.41^{b}$ & $583.40 \pm 3.65^{b}$ & $181.10 \pm 1.93^{c}$ & $531.43 \pm 2.94^{b}$ \\
\hline EDE & $263.61 \pm 3.71^{b}$ & $121.70 \pm 2.05^{c}$ & $366.81 \pm 3.12^{d}$ & $120.53 \pm 2.52^{d}$ & $279.51 \pm 2.57^{\mathrm{e}}$ \\
\hline EDEW & $144.71 \pm 3.44^{c}$ & $78.02 \pm 1.21^{d}$ & $317.80 \pm 3.35^{e}$ & $100.40 \pm 1.81^{\mathrm{e}}$ & $331.46 \pm 2.42^{d}$ \\
\hline EDM & $351.33 \pm 4.54^{\mathrm{a}}$ & $142.43 \pm 2.51^{c}$ & $405.01 \pm 3.57^{c}$ & $210.23 \pm 3.41^{b}$ & $446.3 \pm 3.52^{c}$ \\
\hline Rutin & - & $80.74 \pm 2.25^{d}$ & - & - & - \\
\hline AA & $26.65 \pm 2.41^{d}$ & - & $244.45 \pm 2.35^{f}$ & - & - \\
\hline Gallic acid & - & $45.97 \pm 1.92^{\mathrm{e}}$ & - & - & - \\
\hline EDTA & - & - & - & - & $189.85 \pm 1.53^{f}$ \\
\hline Catechin & - & - & - & $78.57 \pm 2.15^{f}$ & - \\
\hline
\end{tabular}

EDH E. dracunculoides n-hexane extract, EDA E. dracunculoides aqueous extract, EDE E. dracunculoides ethyl acetate, EDEW E. dracunculoides ethyl acetate + water extract, EDM E. dracunculoides methanol extract

Values are presented as means \pm SD $(n=3)$. Means with different superscript $\left({ }^{\text {a-f }}\right)$ letters in the column are significantly $(P<0.01)$ different from one another

recorded in EDE following the rule that polar solvents dissolve more compounds in comparison to that of nonpolar in short time at room temperature [36]. Present studies are in agreement to the concept of polarity based extraction with the experiment run by [37] on Maytenus royleanus leaves and [38] evaluating Rumex hastatus roots.

Preliminary qualitative phytochemical screening gives a clue for the medicinal aptitude of the herb. In the conducted study bioactive components that impart biologically active nature to the plant were screened and results ensured the presence of terpenoids, coumarins, flavonoids, tannins, phenols, alkaloids, saponins, and betacyanin. These variant compounds ranging from low polarity to high polarity were extracted in their respective solvents.

The EDH was analyzed through GC-MS and it was found to contain 30 chemical constituents eluted between 6.36 and $40.10 \mathrm{~min}$. Maximum proportion was contributed by terpenoids followed by lactones, steroids,

Table 6 Correlation of $\mathrm{IC}_{50}$ values of different antioxidant activities of E. dracunculoides with total phenolic and total flavonoid contents

\begin{tabular}{lll}
\hline Antioxidant Activity & \multicolumn{2}{l}{ Correlation $\mathrm{R}^{2}$} \\
\cline { 2 - 3 } & $\mathrm{TFC}$ & $\mathrm{TPC}$ \\
\hline DPPH radical scavenging activity & $0.9028^{* *}$ & 0.5687 \\
Hydroxyl radical scavenging activity & $0.9505^{* *}$ & $0.7224^{*}$ \\
Iron chelating assay & $0.9361^{* *}$ & $0.8232^{*}$ \\
Nitric Oxide radical scavenging Activity & $0.9638^{* *}$ & $0.6822^{*}$ \\
$\beta$ - carotene bleaching scavenging activity & $0.7579^{*}$ & $0.8965^{* *}$ \\
Phosphomolybdenum assay & $0.7429^{*}$ & $0.893^{* *}$ \\
Reducing power assay & $0.9812^{* *}$ & $0.7349^{*}$ \\
\hline
\end{tabular}

Column with different superscripts are significantly different ${ }^{*}{ }^{* * *}$, indicate $P<0.05$, $P<0.01$. TFC total flavonoid content, TPC total phenolic content phenols and heterocycles. GC-MS analyses of EDH validated the concept of polarity based extraction as the most of the compounds identified were of non-polar nature.

In the present study through HPLC analysis of EDEW presence of four compounds; rutin, catechin, caffeic acid and quercetin was evaluated. Rutin was present in maximum amount $(65.8 \pm 2.2 \mu \mathrm{g} / \mathrm{mg}$ dry extract) followed by catechin $(15.3 \pm 1.2 \mu \mathrm{g} / \mathrm{mg}$ dry extract). Rutin is a known and well reputed secondary metabolite of plants with admirable hepatoprotective, anti-inflammatory and antioxidant activities [39]. Another well-known polyphenolic compound, catechin has good antioxidant potential and provides a reliable defense wall against free radicals. Catechin provides protection against neurological disorders, inflammation and apoptosis. The admiring amount of standard antioxidant phenolic compounds in EDEW

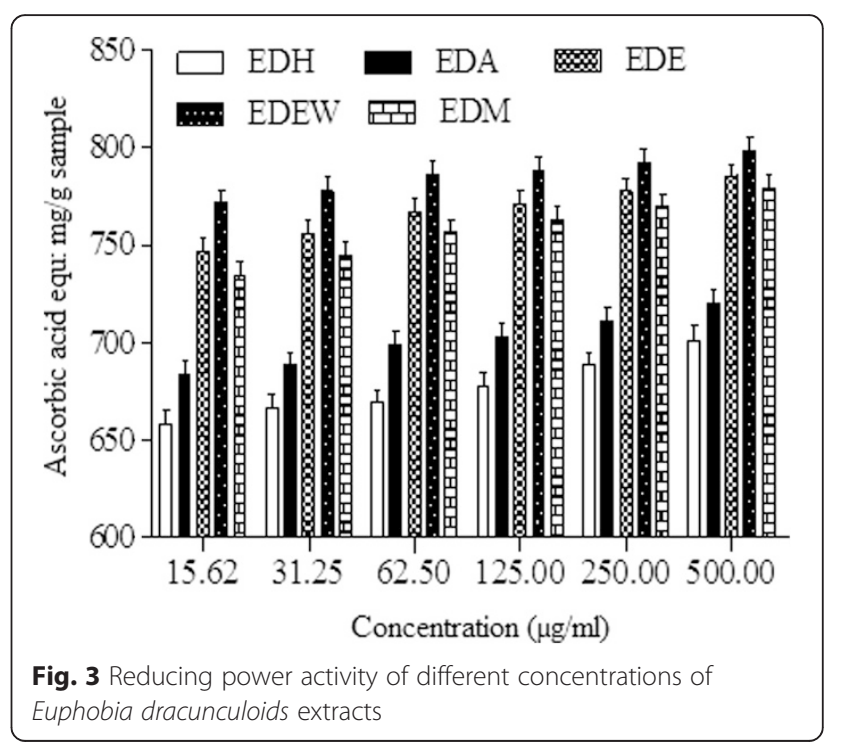




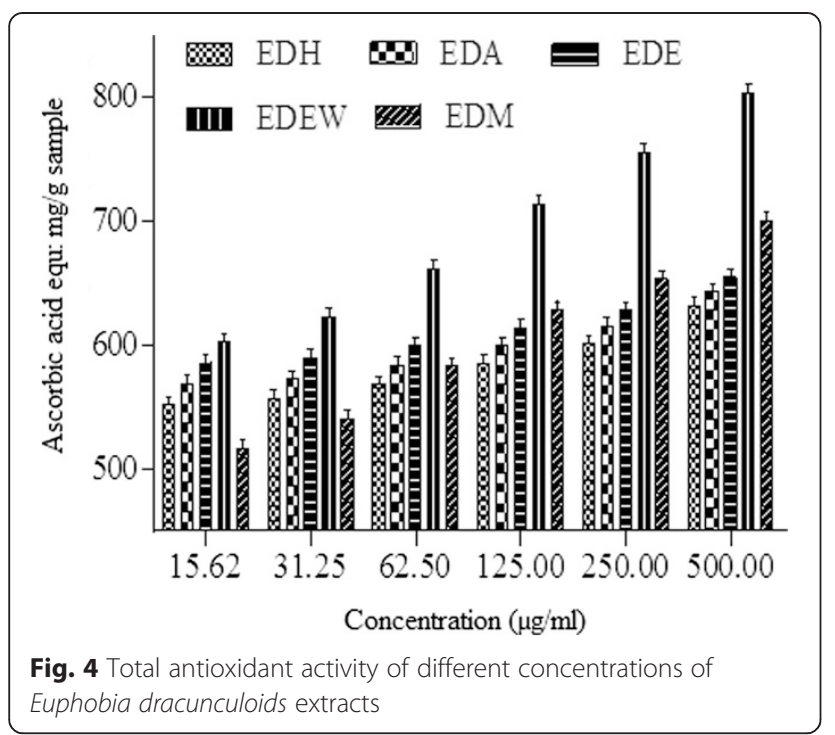

is the justification of raised antioxidant potential of this extract. Significant correlation between TPC and TFC with that of antioxidant assays also validates the HPLC results.

Natural antioxidants have attained worth reputation in treating several diseases and have raised the value of folk herbal medicines in the modern era. The ability of DPPH radical scavenging is considered as a milestone while assessing the antioxidant aptitude of a crude plant extract or an isolated pure compound. It is a very short timed assay for appraising the antioxidant abilities and has worth economic values [40]. In this study EDEW showed the maximum scavenging activity with lowest
$\mathrm{IC}_{50}$ value, followed by EDE $<\mathrm{EDM}<\mathrm{EDA}<\mathrm{EDH}$. Greater quantity of phenolics and flavonoids extracted in EDEW might exhibit good scavenging abilities due to donation of electron or hydrogen to stabilize DPPH free radicals. None of the five extracts showed $\mathrm{IC}_{50}$ below ascorbic acid used as standard. Though [41] and [42] used different techniques for extraction yet our results are consolidating their findings. The results reported in this study indicated a good correlation with the TFC while non-significant correlation was recorded with TPC. The strong correlation of $\mathrm{IC}_{50}$ values with TFC might be attributed by the presence of active flavonoids such as myricetin, rutin, caffeic acid and catechin.

Antioxidant potential of a plant crude extract or compound can also be estimated by its ability to oxidize linoleic acid. $\beta$-carotene is a fat soluble hydrocarbon with yellowish orange color. Linoleic acid hydroperoxides on reaction with $\beta$-carotene bleaches its color. This is due to the fact that $\beta$-carotene forms a complex with linoleic acid and oxidizes it. This consumption of $\beta$ carotene causes the reduction of bright yellow color to light milky color. Now the presence of an antioxidant in the reaction mixture checks the consumption of $\beta$ carotene by acting on linoleic acid free radicals. As the $\beta$-carotene is released from the complex between it and linoleic acid, the yellow color of the reaction mixture is regained. Hence stronger the antioxidant present in the reaction mixture brighter will be the color and higher will be its optical density [43]. In the present study, EDEW and EDE showed the best activity with lower $\mathrm{IC}_{50}$ values. Significantly good correlation of $\mathrm{IC}_{50}$ values was observed with TPC $(P<0.01)$ and TFC $(P<0.05)$

Table 7 Effect of E. dracunculoides on carrageenan-induced paw edema in rat

\begin{tabular}{|c|c|c|c|c|c|}
\hline \multirow{2}{*}{$\begin{array}{l}\text { Treatment } \\
\mathrm{mg} / \mathrm{kg}\end{array}$} & \multicolumn{5}{|c|}{ Edema volume $(\mathrm{ml}) /$ Percent edema inhibition } \\
\hline & $\mathrm{Oh}$ & $1 \mathrm{~h}$ & $2 \mathrm{~h}$ & $3 \mathrm{~h}$ & $4 \mathrm{~h}$ \\
\hline DMSO (2 ml) & $0.506 \pm 0.046$ & $0.776 \pm 0.045$ & $0.710 \pm 0.021$ & $0.671 \pm 0.017$ & $0.600 \pm 0.021$ \\
\hline \multirow[t]{2}{*}{ DIC (10) } & $0.551 \pm 0.056$ & $0.706 \pm 0.056$ & $0.640 \pm 0.049$ & $0.613 \pm 0.049$ & $0.586 \pm 0.056$ \\
\hline & & $42.862 \pm 5.614^{\mathrm{ab}}$ & $56.903 \pm 8.443^{\mathrm{ab}}$ & $69.975 \pm 5.730^{\mathrm{a}}$ & $78.823 \pm 6.395^{\mathrm{a}}$ \\
\hline \multirow[t]{2}{*}{ EDH (300) } & $0.548 \pm 0.022$ & $0.685 \pm 0.033$ & $0.630 \pm 0.021$ & $0.615 \pm 0.018$ & $0.600 \pm 0.023$ \\
\hline & & $49.652 \pm 7.649^{a}$ & $60.171 \pm 3.690^{\mathrm{a}}$ & $67.524 \pm 8.004^{\mathrm{a}}$ & $68.660 \pm 10.502^{\mathrm{a}}$ \\
\hline \multirow[t]{2}{*}{ EDA (300) } & $0.548 \pm 0.035$ & $0.751 \pm 0.027$ & $0.696 \pm 0.030$ & $0.683 \pm 0.032$ & $0.651 \pm 0.031$ \\
\hline & & $24.960 \pm 7.283^{c}$ & $27.492 \pm 5.730^{d}$ & $34.028 \pm 9.170^{c}$ & $37.156 \pm 6.297^{c}$ \\
\hline \multirow[t]{2}{*}{ EDE (300) } & $0.560 \pm 0.037$ & $0.730 \pm 0.016$ & $0.676 \pm 0.037$ & $0.651 \pm 0.039$ & $0.640 \pm 0.026$ \\
\hline & & $37.307 \pm 8.113^{\mathrm{abc}}$ & $43.014 \pm 12.271^{b c}$ & $55.269 \pm 7.215^{\mathrm{ab}}$ & $51.384 \pm 8.623^{b}$ \\
\hline \multirow[t]{2}{*}{ EDEW (300) } & $0.520 \pm 0.046$ & $0.705 \pm 0.045$ & $0.643 \pm 0.030$ & $0.633 \pm 0.044$ & $0.608 \pm 0.039$ \\
\hline & & $31.752 \pm 3.883^{b c}$ & $39.746 \pm 10.125^{\mathrm{cd}}$ & $44.648 \pm 9.127^{b c}$ & $46.302 \pm 8.975^{b c}$ \\
\hline \multirow[t]{2}{*}{ EDM (300) } & $0.545 \pm 0.032$ & $0.738 \pm 0.026$ & $0.683 \pm 0.031$ & $0.676 \pm 0.026$ & $0.653 \pm 0.039$ \\
\hline & & $28.665 \pm 11.396^{c}$ & $32.394 \pm 8.443^{c d}$ & $35.662 \pm 12.938^{c}$ & $34.107 \pm 8.975^{c}$ \\
\hline
\end{tabular}

EDH E. dracunculoides n-hexane extract, EDA E. dracunculoides aqueous extract, EDE E. dracunculoides ethyl acetate, EDEW E. dracunculoides ethyl acetate + water extract, EDM E. dracunculoides methanol extract (EDM), DIC diclofenac sodium

Data values shown represent mean \pm SD $(n=6)$. Means with different superscript $\left.{ }^{(-d}\right)$ letters in the column are significantly $(P<0.05)$ different from one another 
Table 8 Analgesic activity of E. dracunculoides of hot plate test in rat

\begin{tabular}{|c|c|c|c|c|c|c|c|}
\hline \multirow{2}{*}{$\begin{array}{l}\text { Treatment } \\
(\mathrm{mg} / \mathrm{kg})\end{array}$} & \multicolumn{4}{|c|}{ Latency time sec } & \multicolumn{3}{|l|}{ Percent analgesia } \\
\hline & $\mathrm{Oh}$ & $30 \mathrm{~min}$ & $60 \mathrm{~min}$ & $90 \mathrm{~min}$ & $30 \mathrm{~min}$ & $60 \mathrm{~min}$ & $90 \mathrm{~min}$ \\
\hline DMSO (2 ml) & $9.000 \pm 0.894$ & $9.833 \pm 1.169$ & $10.167 \pm 0.752$ & $10.167 \pm 0.752$ & $3.971 \pm 3.588^{d}$ & $5.490 \pm 3.378^{e}$ & $5.490 \pm 3.378^{e}$ \\
\hline Morphine (10) & $9.333 \pm 1.032$ & $21.000 \pm 1.549$ & $25.667 \pm 1.032$ & $22.500 \pm 1.048$ & $56.160 \pm 9.114^{b}$ & $78.889 \pm 5.853^{\mathrm{a}}$ & $63.632 \pm 5.449^{\mathrm{ab}}$ \\
\hline EDH (300) & $9.833 \pm 1.169$ & $21.667 \pm 1.633$ & $24.833 \pm 1.169$ & $24.000 \pm 1.095$ & $58.304 \pm 9.974^{\mathrm{a}}$ & $74.309 \pm 5.864^{b}$ & $70.206 \pm 5.445^{\mathrm{a}}$ \\
\hline EDA (300) & $9.666 \pm 0.816$ & $14.167 \pm 1.602$ & $15.167 \pm 1.169$ & $16.833 \pm 0.752$ & $22.164 \pm 6.680^{c}$ & $26.964 \pm 6.193^{d}$ & $35.223 \pm 3.210^{d}$ \\
\hline EDE (300) & $10.000 \pm 0.894$ & $16.000 \pm 1.414$ & $22.333 \pm 1.211$ & $21.333 \pm 1.032$ & $29.804 \pm 8.470^{b c}$ & $61.811 \pm 4.528^{b}$ & $56.508 \pm 6.363^{b c}$ \\
\hline EDEW (300) & $9.666 \pm 0.816$ & $15.500 \pm 1.048$ & $19.333 \pm 1.633$ & $19.667 \pm 1.032$ & $28.676 \pm 4.528^{b c}$ & $47.331 \pm 9.410^{c}$ & $49.204 \pm 4.254^{c}$ \\
\hline EDM (300) & $9.666 \pm 0.816$ & $17.833 \pm 1.472$ & $20.000 \pm 1.788$ & $19.500 \pm 1.048$ & $40.196 \pm 6.553^{b}$ & $50.959 \pm 7.486^{b c}$ & $48.248 \pm 5.943^{c}$ \\
\hline
\end{tabular}

EDH E. dracunculoides n-hexane extract, EDA E. dracunculoides aqueous extract, EDE E. dracunculoides ethyl acetate, EDEW E. dracunculoides ethyl acetate + water extract, EDM E. dracunculoides methanol extract

Data values shown represent mean \pm SD $(n=6)$. Means with different superscript $\left.{ }^{\left({ }^{-e}\right.}\right)$ letters in the column are significantly $(P<0.05)$ different from one another

which defines that more active constituents exhibiting inhibition of $\beta$-carotene bleaching belong to the TPC while constituents having moderate activity are present in TFC.

Hydroxyl radical is generated during various biochemical reactions in the body. It is a short lived, very toxic free radical having affinity for biomolecules like lipids, proteins, amino acids, sugars, deoxyribonucleic acids, leading to cancer, mutagenesis and cytotoxicity [44]. Superoxide dismutase converts superoxide radical into hydrogen peroxide which is converted to a highly reactive hydroxyl radical. Evidence of $\bullet \mathrm{OH}$ scavenging activity by various extracts was obtained through deoxyribose system [45]. In vivo hydroxyl radicals are probably produced through Haber-Weiss reaction where $\mathrm{Fe}^{+3}$ is reduced to $\mathrm{Fe}^{+2}$ with the help of $\mathrm{O}_{2}^{--}$which leads to initiation of Fenton reaction between $\mathrm{H}_{2} \mathrm{O}_{2}$ and $\mathrm{Fe}^{+2}$ [46]. In the present study EDEW and EDE extracts showed the best activity with lower $\mathrm{IC}_{50}$ values. A significant correlation of $\mathrm{IC}_{50}$ values was present with both TPC and TFC. Our results are in well accordance to the findings of [47] who reported methanol extract of Dicliptera roxburghiana as the most active to scavenge hydroxyl radicals.

At $\mathrm{pH} 7.4$ a vigorous generation of nitric oxide from sodium nitroprusside occurs which further in favorable conditions viz aerobic conditions and aqueous solution react with oxygen and convert to nitrite ions, that can be appraised by Griess reagent. These nitrite ions impart pink color to the reaction mixture. Entities with $\mathrm{NO}^{-}$ scavenging abilities hinder the nitrite ion production by consuming the available oxygen. In our study EDEW and EDE showed comparatively good results than rest of the extracts and significant correlation of $\mathrm{IC}_{50}$ values was observed with TPC and TFC. This is due to the fact that EDEW and EDE are rich in bioactive phenolic and polyphenolics which have a fine tendency to scavenge $\mathrm{NO}^{-}$free radicals that are responsible for oxidative stress. Research of [48] and [49] is in agreement to our findings.

Idea of iron chelating assay is based on the principle of scavenger's ability to decolorize the iron-ferrozine complex. Ferrozine quickly reacts with the iron (II) to form water soluble colored complex. Scavenging entity present in the extract forms chelates with iron (II) hindering the iron-ferrozine complex formation and ultimately lowering the color intensity of the solution. In the present study EDE exhibited the best performance with lowest $\mathrm{IC}_{50}$ among all extracts in comparison to EDTA used as standard. Significant correlation of $\mathrm{IC}_{50}$ values was expressed with TFC $(P<0.01)$ and with TPC $(P<0.05)$ indicating that more active flavonoids constituents for iron chelation activity.

The basic principle of phosphomolybdate assay is that antioxidant species reduces Mo (IV) to Mo (V) and this reduced form of Mo forms complex with phosphate at acidic $\mathrm{pH}$ and raised temperature impart dark green color to the final solution [50]. The electron/ hydrogen donating pattern of antioxidants depends upon its structure and series of redox reactions occurring in the activity [51]. EDEW and EDE showed admiring results than that of EDM, EDA and EDH. The assay showed a good correlation with TPC as well as TFC. Jan et al. [52] also reported aqueous extract as the best extract in phosphomolybdenum assay, followed by methanol. Moreover, significant correlation has also been reported with TPC which is in consensus with the present study but the method of extraction was a bit different, which suggests that this methodology made no difference in extracting bioactive compounds responsible for total antioxidant activity of the plant extract.

Reducing power of E. dracunculoides was determined by using the potassium ferricynide reduction method. In this assay iron $\left(\mathrm{Fe}^{+3}\right)$ in ferric chloride is converted to ferrous $\left(\mathrm{Fe}^{+2}\right)$ by antioxidant compound/extract resulting 
in conversion of yellow color of the test solution to green. The intensity of green colour is directly proportional to the reducing power of the sample. Basically reducing power of the sample is due to hydrogen donating ability of antioxidants to the free radicals [53]. The assay was significantly correlated with TPC and TFC. This assay results in a pattern of EDEW $>\mathrm{EDE}>\mathrm{EDM}>\mathrm{EDA}>$ $\mathrm{EDH}$ at $250 \mu \mathrm{g} / \mathrm{ml}$. Our study has been supported by the report of [38] that crude methanol extract was the best sample in reducing power assay after butanol.

Carrageenan is widely used to induce paw edema in rodents to demonstrate anti-inflammatory effect of drugs or herbs. Carrageenan-induced inflammation is considered to be a biphasic model. Initial stage (1-2 h) contributes to the release of histamine, bradykinin and serotonin which mediates the increased synthesis of prostaglandins from surrounding tissues of the injured site. The later phase $(3-4 \mathrm{~h})$ is characterized by the elevated level of prostaglandins mediated by the elevated release of leukotrienes and bradykinin. During this phase the cyclo-oxygenase-2 (COX-2) converts arachidonic acid into prostaglandins which is a key factor of inflammation maintenance. In this experiment carrageenan induced edema in the hind paw of rats was inhibited by all the extracts. EDH significantly inhibited the edema formation; 1, 2, 3 and $4 \mathrm{~h}$ after the injection of carrageenan in the hind paw of rats. These results indicated that the phyto-constituents present in EDH inhibited the inflammatory mediators of the initial as well as late phase of inflammation induced with carrageenan. The other extracts however, more effectively inhibited the edema during the initial phase. Steroids are established antiinflammatory agents which inhibit the production of prostaglandin not only by inducing the biosynthesis of phospholipase $\mathrm{A}_{2}$ inhibitor but also by raising the level of cyclo-oxygenase/PGE isomerase [54-56]. In the present investigation GC-MS analysis of EDH revealed the existence of stigmasta-5, 22-dien-3-ol, (3á,22E)(CAS); a phytosterol possesses strong anti-inflammatory and analgesic properties probably contributing towards the anti-inflammatory properties of $\mathrm{EDH}[57,58]$. The standard drug also exhibited the strong anti-inflammatory potential after 2, 3 and $4 \mathrm{~h}$ of carrageenan injection to rats. Diclofenac sodium like other NSAIDs targets the COX-2 enzyme thereby inhibiting the formation of the paw edema. The anti-inflammatory results obtained with EDH in both phases might be attributed by the counteraction of anti-inflammatory agents such as sterols and terpenoids [59]. The anti-inflammatory effects obtained by the polar extracts; EDE, EDA, EDEW and EDM during the initial phase might be attributed by the presence of flavonoids (rutin, catechin, caffeic acid and myricetin) and other constituents. Anti-inflammatory activities of rutin, catechin and caffeic acid have been well documented [60]. Our studies are in consensus with [60] and $[61,62]$ who generated the same anti-inflammatory results of Acacia hydaspica and Boerhavia procumbens in rats.

Thermal nociception models such as, hot plate test was used to evaluate the central analgesic activity. In this study all the extracts of E. dracunculoides showed analgesic effect in the hot plate test. EDH exhibited the best potent analgesic activity among the extracts with 74.309 $\pm 5.864 \%$ inhibition of pain sensation followed by EDE $(61.811 \pm 4.528 \%)$ in comparison to morphine $(78.889 \pm$ $5.853 \%)$ after 60 min of drug administration. Morphine induces analgesic effect through activation of opioid receptors and the apparent similarity between the results of extracts with standard morphine, indicates that they might work in a same manner to reduce pain sensation. The presence of steroids in EDH might induce the biosynthesis of phospholipase $\mathrm{A}_{2}$ inhibitor and cyclooxygenase/PGE isomerase which in turn inhibits the pain producing prostaglandins. Our results are in agreements to the findings of Mondal et al. [63] evaluating Alternanthera sessilis as analgesic agent. Backhouse et al. [64] also reported the same results while evaluating Buddleja globosa as analgesic and anti-inflammatory agent.

\section{Conclusion}

The present results suggest that the flavonoids in $E$. dracunculoides might be the key players in scavenging of oxidative stress inducing species while flavonoids along with sterols and terpenoids alleviate the inflammation and pain inducing mediators.

\section{Competing interests}

The authors declare that they have no competing interests.

\section{Authors' contributions}

MM collect the plant and data for various activities. MRK provide the nacessary facilities and edited the manuscript. IH provided help in HPLC. NAS,MAF, SU, AS, ZZ, TY and MS provide help in experimentation, data collection and analysis. All authors read and approved the final manuscript.

Authors' information

Not applicable.

\section{Acknowledgments}

MRK is strongly acknowledged for his kind supervision, expert guidance and generous facilitation of all necessary materials and equipments. Dr. Bushra Mirza is also highly acknowledged for her assistance in HPLC.

\section{Author details}

${ }^{1}$ Department of Biochemistry, Faculty of Biological Sciences, Quaid-i-Azam University, Islamabad, Pakistan. ${ }^{2}$ Department of Biosciences, COMSATS Institute of Information Technology, Islamabad, Pakistan. ${ }^{3}$ Department of Pharmacy, Faculty of Biological Sciences, Quaid-i-Azam University, Islamabad, Pakistan.

Received: 9 June 2015 Accepted: 21 September 2015

Published online: 07 October 2015

\section{References}

1. Okwu DE, Uchenna NF. Exotic multifaceted medicinal plants of drugs and pharmaceutical industries. Afr J Biotechnol. 2009;8:25. 
2. Mahmood A, Mahmood A, Tabassum A. Ethnomedicinal survey of plants from District Sialkot, Pakistan. J App Pharm. 2011;2:212-20.

3. Birben E, Sahiner UM, Sackesen C, Erzurum S, Kalayci O. Oxidative stress and antioxidant defense. World Allergy Organ J. 2012;5(1):9

4. Shah NA, Khan MR, Naz K, Khan MA. Antioxidant potential, DNA protection, and HPLC-DAD analysis of neglected medicinal Jurinea dolomiaea roots. BioMed Res Int. 2014;2014:726241.

5. Cordell GA. Changing strategies in natural products chemistry. Phytochemistry. 1995;40(6):1585-612.

6. Kang JY, Khan MN, Park NH, Cho JY, Lee MC, Fujii H. Antipyretic, analgesic and anti-inflammatory activities of the seaweed Sargassum fulvellum and Sargassum thunbergii in mice. J Ethnopharmacol. 2008;116(1):187-90.

7. Jassbi AR. Chemistry and biological activity of secondary metabolites in Euphorbia from Iran. Phytochemistry. 2006;67(18):1977-84.

8. Bigoniya P, Rana A. A comprehensive phyto-pharmacological review of Euphorbia neriifolia Linn. Phcog Rev. 2008;2(4):57.

9. Bani S, Kaul A, Jaggi B, Suri K, Suri O, Sharma O. Anti-inflammatory activity of the hydrosoluble fraction of Euphorbia royleana latex. Fitoterapia. 2000;71(6):655-62.

10. Kumar S, Malhotra R, Kumar D. Euphorbia hirta: Its chemistry, traditional and medicinal uses, and pharmacological activities. Phcog Rev. 2010;4(7):58.

11. Patil SB, Naikwade NS, Magdum CS. Review on phytochemistry and pharmacological aspects of Euphorbia hirta Linn. JPRHC. 2009;1(1):113-33.

12. Barla A, Öztürk $M$, Kültür \$̧, Öksüz S. Screening of antioxidant activity of three Euphorbia species from Turkey. Fitoterapia. 2007;78(6):423-5.

13. Rahman MA, Mossa JS, Al-Said MS, Al-Yahya MA. Medicinal plant diversity in the flora of Saudi Arabia 1: a report on seven plant families. Fitoterapia. 2004;75(2):149-61.

14. Sharma J, Painuli R, Gaur R. Plants used by the rural communities of district Shahjahanpur, Uttar Pradesh. Indian J Tradit Know. 2010;9(4):798-803.

15. Sikarwar R, Bajpai A, Painuli R. Plants used as veterinary medicines by aboriginals of Madhya Pradesh, India. Pharma Biol. 1994;32(3):251-5.

16. Wang L, Ma Y-T, Sun Q-Y, Li X-N, Yan Y, Yang J, et al. Structurally diversified diterpenoids from Euphorbia dracunculoides. Tetrahedron. 2015;71(34):5484-93.

17. Qurainy F, Khan S, Ali MA, Hemaid M, Ashraf M. Authentication of Ruta graveolens and its adulterant using internal transcribed spacer (ITS) sequences of nuclear ribosomal DNA. Pak J Bot. 2011;43(3):1613-20.

18. Parray SA, Bhat J, Ahmad G, Jahan N, Sofi G, IFS M. Ruta graveolens: from traditional system of medicine to modern pharmacology: an overview. Am J Pharm Tech Res. 2012;2(2):239-52.

19. J H: Phytochemical Methods. A guide to modern techniques of plant analysis. 3rd ed. New York: Chapman \& Hall Co; 1998. p. 1-302.

20. Trease GE, Evans EW. Pharmacognosy. 11th ed. London: Braillar Tiridel Can Macmillian Publishers; 1989. p. 60-75.

21. Kim D-O, Jeong SW, Lee CY. Antioxidant capacity of phenolic phytochemicals from various cultivars of plums. Food chem. 2003;81(3):321-6.

22. Park Y-S, Jung S-T, Kang S-G, Heo BG, Arancibia-Avila P, Toledo F, et al. Antioxidants and proteins in ethylene-treated kiwifruits. Food Chem. 2008;107(2):640-8

23. Cha J-D, Jeong M-R, Jeong S-I, Moon S-E, Kim J-Y, Kil B-S, et al. Chemical composition and antimicrobial activity of the essential oils of Artemisia scoparia and A. capillaris. Planta Med. 2005;71(2):186-90.

24. Zu Y, Li C, Fu Y, Zhao C. Simultaneous determination of catechin, rutin, quercetin kaempferol and isorhamnetin in the extract of sea buckthorn (Hippophae rhamnoides L.) leaves by RP-HPLC with DAD. J Pharmaceut Biomed. 2006:41(3):714-9.

25. Brand-Williams W, Cuvelier M, Berset C. Use of a free radical method to evaluate antioxidant activity. Food Sci Technol-Leb. 1995:28(1):25-30.

26. Halliwell B, Gutteridge JM. Formation of a thiobarbituric-acid-reactive substance from deoxyribose in the presence of iron salts: the role of superoxide and hydroxyl radicals. FEBS Lett. 1981;128(2):347-52.

27. Bhaskar $\mathrm{H}$, Balakrishnan N. In vitro antioxidant property of laticiferous plant species from western ghats Tamilnadu, India. Int J Health Res. 2009;2:2

28. Dastmalchi K, Dorman HD, Oinonen PP, Darwis Y, Laakso I, Hiltunen R. Chemical composition and in vitro antioxidative activity of a lemon balm (Melissa officinalis L) extract. Food Sci Technol-Leb. 2008:41(3):391-400.

29. Elzaawely AA, Xuan TD, Koyama H, Tawata S. Antioxidant activity and contents of essential oil and phenolic compounds in flowers and seeds of Alpinia zerumbet (Pers.) BL Burtt. \& RM Sm. Food Chem. 2007;104(4):1648-53.

30. Siddhuraju P, Mohan P, Becker K. Studies on the antioxidant activity of Indian Laburnum (Cassia fistula L.): a preliminary assessment of crude extracts from stem bark, leaves, flowers and fruit pulp. Food Chem. 2002;79(1):61-7.

31. Umamaheswari $M$, Chatterjee $\mathrm{T}$. In vitro antioxidant activities of the fractions of Coccinia grandis L. leaf extract. Afr J Tradit Complem Med. 2008;5(1):61-73

32. Winter CA, Risley EA, Nuss GW. Anti-inflammatory and antipyretic activities of indo-methacin, 1-(p-chlorobenzoyl)-5-methoxy-2-methyl-indole-3-acetic acid. J Pharmacol Exp Ther. 1963;141(3):369-76.

33. Muhammad N, Saeed M, Khan H. Antipyretic, analgesic and anti-inflammatory activity of Viola betonicifolia whole plant. BMC Complem Altern Med. 2012;12(1):59.

34. Petrovska BB. Historical review of medicinal plants' usage. Pharmacogn Rev. 2012;6(11):1

35. Jones WP, Kinghorn AD. Extraction of plant secondary metabolites. In Natural products isolation. Volume 20, edn.: Springer; 2005: 323-351.

36. Pin K, Chuah AL, Rashih AA, Mazura M, Fadzureena J, Vimala S, et al. Antioxidant and anti-inflammatory activities of extracts of betel leaves (Piper betle) from solvents with different polarities. J Trop For Sci. 2010;448-455.

37. Shabbir M, Khan MR, Saeed N. Assessment of phytochemicals, antioxidant, anti-lipid peroxidation and anti-hemolytic activity of extract and various fractions of Maytenus royleanus leaves. BMC Complem Altern Med. 2013;13(1):143

38. Sahreen S, Khan MR, Khan RA. Comprehensive assessment of phenolics and antiradical potential of Rumex hastatus D. Don. roots. BMC Complem Altern Med. 2014;14(1):47.

39. Kubola J, Siriamornpun S. Phytochemicals and antioxidant activity of different fruit fractions (peel, pulp, aril and seed) of Thai gac (Momordica cochinchinensis Spreng). Food Chem. 2011;127(3):1138-45.

40. Khan MA, Rahman AA, Islam S, Khandokhar P, Parvin S, Islam MB, et al. A comparative study on the antioxidant activity of methanolic extracts from different parts of Morus alba L.(Moraceae). BMC Res Notes. 2013;6(1):24

41. Khan RA, Khan MR, Sahreen S, Ahmed M. Evaluation of phenolic contents and antioxidant activity of various solvent extracts of Sonchus asper (L.) Hill. Chem Cent J. 2012;6(1):12.

42. Bokhari J, Khan MR, Shabbir M, Rashid U, Jan S, Zai JA. Evaluation of diverse antioxidant activities of Galium aparine. Spectrochim Acta A. 2013:102:24-9.

43. Tan Z, Shahidi F. Antioxidant activity of phytosteryl phenolates in different model systems. Food Chem. 2013;138(2):1220-4.

44. Kohen R, Nyska A, Invited review. Oxidation of biological systems: oxidative stress phenomena, antioxidants, redox reactions, and methods for their quantification. Toxicol Pathol. 2002;30(6):620-50.

45. Wu N, Kong Y, Fu Y, Zu Y, Yang Z, Yang M, et al. In vitro antioxidant properties, DNA damage protective activity, and xanthine oxidase inhibitory effect of cajaninstilbene acid, a stilbene compound derived from pigeon pea Cajanus cajan (L.) Millsp.] leaves. J Agr Food Chem. 2010;59(1):437-43.

46. Kehrer JP. The Haber-Weiss reaction and mechanisms of toxicity. Toxicology. 2000;149(1):43-50.

47. Ahmad B, Khan MR, Shah NA, Khan RA. In vitro antioxidant potential of Dicliptera roxburghiana. BMC Complem Altern Med. 2013;13(1):140.

48. Duenas M, Hernandez T, Estrella I. Assessment of in vitro antioxidant capacity of the seed coat and the cotyledon of legumes in relation to their phenolic contents. Food Chem. 2006;98(1):95-103.

49. Kilani S, Sghaier MB, Limem I, Bouhlel I, Boubaker J, Bhouri W, et al. In vitro evaluation of antibacterial, antioxidant, cytotoxic and apoptotic activities of the tubers infusion and extracts of Cyperus rotundus. Bioresource Technol. 2008;99(18):9004-8.

50. Prieto $P$, Pineda M, Aguilar M. Spectrophotometric quantitation of antioxidant capacity through the formation of a phosphomolybdenum complex: specific application to the determination of vitamin E. Anal Biochem. 1999;269(2):337-41.

51. Lee SK, Mbwambo Z, Chung H, Luyengi L, Gamez E, Mehta R, et al. Evaluation of the antioxidant potential of natural products. Comb Chem High T Scr. 1998;1(1):35-46.

52. Jan S, Khan MR, Rashid U, Bokhari J. Assessment of antioxidant potential, total phenolics and flavonoids of different solvent fractions of Monotheca buxifolia fruit. Osong Public Health and Research Perspectives. 2013:4(5):246-54

53. Gordon M. The mechanism of antioxidant action in vitro. In: Food antioxidants. edn.: Springer; 1990: 1-18.

54. Flower R, Blackwell G. Anti-inflammatory steroids induce biosynthesis of a phospholipase A2 inhibitor which prevents prostaglandin generation. Nature. 1979;278:456-9. 
55. Uma B, Yegnanarayan R, Pophale P, Zambare M, Somani R. Antinociceptive evaluation of an ethanol extract of Achyranthes aspera (agadha) in animal models of nociception. Int J Phyto. 2010;2:4.

56. Barnes PJ, Adcock I, Spedding M, Vanhoutte PM. Anti-inflammatory actions of steroids: molecular mechanisms. Trends Pharmacol Sci. 1993;14(12):436-41.

57. Gomez M, Saenz M, Garcia M, Fernandez M. Study of the topical antiinflammatory activity of Achillea ageratum on chronic and acute inflammation models. Z Naturforsch C. 1999;54(11):937-41.

58. Conforti F, Sosa S, Marrelli M, Menichini F, Statti GA, Uzunov D, et al. In vivo anti-inflammatory and in vitro antioxidant activities of Mediterranean dietary plants. J Ethnopharmacol. 2008;116(1):144-51.

59. Shah SMM, Sadiq A, Shah SMH, Ullah F. Antioxidant, total phenolic contents and antinociceptive potential of Teucrium stocksianum methanolic extract in different animal models. BMC Complem Alten Med. 2014;14(1):181.

60. Afsar T, Khan MR, Razak S, Ullah S, Mirza B. Antipyretic, anti-inflammatory and analgesic activity of Acacia hydaspica R. Parker and its phytochemical analysis. BMC Complem Altern Med. 2015;15(1):136.

61. Bokhari J, Khan MR, Haq IU. Assessment of phytochemicals, antioxidant, and anti-inflammatory potential of Boerhavia procumbens Banks ex Roxb. Toxicol Ind Health. 2015;0748233714567183.

62. Bokhari J, Khan MR. Evaluation of anti-asthmatic and antioxidant potential of Boerhavia procumbens in toluene diisocyanate (TDI) treated rats. J Ethnopharmacol. 2015;172:377-85.

63. Mondal H, Saha S, Awang K, Hossain H, Ablat A, Islam MK, et al. Centralstimulating and analgesic activity of the ethanolic extract of Alternanthera sessilis in mice. BMC Complem Altern Med. 2014;14:398.

64. Backhouse N, Rosales L, Apablaza C, Goïty L, Erazo S, Negrete R, et al. Analgesic, anti-inflammatory and antioxidant properties of Buddleja globosa, Buddlejaceae. J Ethnopharmacol. 2008;116(2):263-9.

\section{Submit your next manuscript to BioMed Central and take full advantage of:}

- Convenient online submission

- Thorough peer review

- No space constraints or color figure charges

- Immediate publication on acceptance

- Inclusion in PubMed, CAS, Scopus and Google Scholar

- Research which is freely available for redistribution 